\title{
Quality of Life and Treatment Satisfaction of Hospitalized and Day Hospital Psychiatric Patients
}

1 Janja Vranješ

1,2Daniela Petrić

1,2Tanja Grahovac Juretić

1 Zdravko Tovilović

${ }^{1}$ Clinic for Psychiatry, University Hospital Centre Rijeka, Croatia

2 Department of Psychiatry and Psychological medicine, Faculty of Medicine Rijeka, Croatia

Article received: 19.08 .2020 .

Article accepted: 03.12.2020.

Author for correspondence:

Zdravko Tovilović

Clinic for Psychiatry, University Hospital Centre Rijeka

Krešimirova 42, 51000 Rijeka, Croatia

E-mail: zdravko.tovilovic@gmail.com

https://doi.org/10.24141/2/5/1/1

Keywords: mental disorders, day hospital, patient satisfaction, quality of life

\section{Abstract}

Introduction. Day hospitals are becoming an increasingly common method of treatment for people with mental disorders in many Croatian psychiatric hospitals, but research examining their effectiveness is still rare.

Aim. The aim of this study was to compare treatment satisfaction and quality of life between patients enrolled in a day hospital program and patients hospitalized on a psychiatric ward.

Methods. The study design was cross-sectional with two outcome measures: treatment satisfaction and quality of life. The study sample consisted of 120 adult patients of the Clinic for Psychiatry of the University Hospital Centre Rijeka. The first group consisted of 60 patients included in the day hospital psychosocial program, while the second group consisted of 60 patients hospitalized on the inpatient ward.

Results. Day hospital patients reported a significantly higher level of overall treatment satisfaction compared to hospitalized patients (mean rank: 55 vs. $17, p=0.000$ ) and were significantly more satisfied in four out of seven different treatment domains: the explanations about treatment (mean rank: 68 vs. 53, $p=0.013$ ), carefulness and precision of medical examination (mean rank: 72 vs. $49, p=0.000$ ), choices about treatment (mean rank: 67 vs. 57, $p=0.027$ ) and feeling of respect (mean rank: 68 vs. 53, $p=0.010$ ). Day hospital patients also reported a significant- 
Iy higher level of overall subjective quality of life (mean: 4.26 vs. 3.71, $p=0.005$ ), being more satisfied with life in general (mean rank: 68 vs. 53, $p=0,018$ ), financial situation (mean rank: 67 vs. $54, p=0.046$ ), accommodation (mean rank: 67 vs. 54, $p=0.041$ ), personal safety (mean rank: 68 vs. $53, p=0.014$ ), people they live with or living alone (mean rank: 71 vs. 50, $p=0.001$ ), relationship with their family (mean rank: 49 vs. $53, p=0.000$ ) and their mental health (mean rank: 69 vs. $52, p=0.008$ ).

Conclusion. Patients treated in the day hospital differed in the observed variables from those hospitalized on the ward, reporting higher levels of treatment satisfaction and higher subjective quality of life. Future studies should focus on different segments of day hospital programs and a broader set of outcomes.

\section{Introduction}

Modern psychiatry encourages the development of outpatient and day hospital psychiatric treatment, with the ultimate goal of helping the patient to reintegrate into the community and prevent its social isolation (1). Day hospitals are a growing form of care for psychiatric patients drawing their roots from the "deinstitutionalization" movement and the consequent transformation of traditional psychiatric hospitals $(2,3)$. The term "deinstitutionalization", in the context of psychiatry, describes the process of closing or reducing the number of large psychiatric hospitals and the establishment of a new model of community-based mental health care (4). Psychiatric care in western countries has gradually transformed itself from a system dominated by large, isolated clinics to smaller open institutions, and generally to a type of treatment that does not separate the patient from his or her primary social environment. The effects of deinstitutionalization vary from country to country depending on their health and social systems and the specificity of national traditions, socio-cultural context and the level of available resources (5). In Europe, most psychiatric day hospitals are designed to provide a variety of treatment programs for their patients, i.e., social support, psychodynamic groups, behavioural interventions, educa- tion, etc. The available treatment programs depend on theoretical settings and therapeutic directions, professional training, goals, target populations, diagnoses, disease intensity and duration $(2,6)$. Almost all major psychiatric clinics in the Republic of Croatia have organized treatment within day hospitals. The programs of day hospitals have many similarities, but they also differ in terms of the scope, breadth and intensity of therapeutic interventions, which is largely conditioned by the capacity, staff and equipment of individual clinics.

Numerous studies have shown that day hospital treatment is as effective or even more effective as inpatient treatment (7) and is associated with better social and general functioning, as well as a reduced rate of rehospitalizations (8). Studies have also shown that treatment in day hospitals is associated with cost reductions ranging from $20.9 \%$ to $36.9 \%$ over hospital care and is associated with greater treatment satisfaction (9). It has also been clearly established that the effective organization of day hospital treatment for acute psychiatric problems is associated with a lower need for hospitalization, while at the same time improving patient's subjective outcomes (10). Furthermore, psychiatric day hospitals appear to be more effective in terms of reducing psychopathology in a shorter period of time. Also, care within a day hospital has been found to reduce the burden on the family of the patient, reduce relapse rates and rehospitalizations, and is associated with a higher subjective quality of life $(2,8,9)$. Commonly used outcomes in the majority of studies of the efficacy of psychiatric day hospitals are the subjective sense of satisfaction with treatment and the quality of life of patients. Different questionnaires and satisfaction scales are used, which are usually applied immediately after the end of the day hospital treatment and possibly during a certain follow-up period.

In the study by Dick et al. (11) 91 patients diagnosed with neurosis, personality disorder, or adjustment disorder, were assigned to a day hospital program or hospitalized at the ward. Clinical outcome measures after the follow-up period did not differ between hospitalized and day hospital patients, however, treatment satisfaction was significantly higher for patients treated at a day hospital (11). In a randomized controlled trial by Priebe et al. (12) 206 voluntarily admitted patients were either assigned to day hospital treatment or hospitalized on a conventional ward. The main outcomes were: level of psychopa- 
thology, satisfaction with treatment and subjective quality of life on discharge, 3 months and 12 months after discharge. Readmission, or indication for acute psychiatric treatment within 3 and 12 months, and costs during the treatment period were also included as a secondary outcome. The results of this study showed, among other things, that treatment satisfaction was significantly higher in patients treated at a day hospital, however, the quality of life did not differ significantly between the patient groups examined (12). An extensive meta-analysis by Marshall et al. (9) on the effectiveness of day hospital compared to inpatient treatment also showed that the results of most of the included studies suggested greater treatment efficacy in day hospitals in terms of treatment satisfaction, reduced hospital days, the need for subsequent hospitalizations, and lower overall treatment costs. However, the results are not consistent when it comes to the effects on reducing the level of symptoms (9). Research into the efficacy of psychiatric day hospital programs in Croatia is relatively rare and typically includes smaller, convenient patient samples. A recent prospective study by Grahovac-Juretić et al. (13) sought to determine the effect of a day hospital psychosocial program on the symptomatology and quality of life of patients with schizophrenia. The results of this study showed that patients included in the day hospital program, compared with those who were not in day care, had a significant reduction in symptoms immediately after the end of the program, but also 6 months later. In addition, patients in the day hospital had a higher quality of life at the end of the study compared with those taking pharmacotherapy alone (13).

The first aim of this study was to compare differences in treatment satisfaction between patients enrolled in a day hospital program and patients hospitalized on a ward. We hypothesized that patients treated within a day hospital would be more satisfied with treatment compared to patients hospitalized on a ward.

The second aim of this study was to compare differences in quality of life between patients enrolled in a day hospital program and patients hospitalized on a ward. We hypothesized that patients treated within a day hospital would have a higher quality of life compared to patients hospitalized on a ward.

\section{Methods}

\section{Participants}

The study design was cross-sectional with two outcome variables: treatment satisfaction and quality of life. The study sample consisted of 120 adult patients of the Psychiatry clinic, Clinical Hospital Centre Rijeka. The first group consisted of 60 patients included in the day hospital psychosocial program, while the second group consisted of 60 patients hospitalized on the inpatient ward. The participants were assigned to each group at the suggestion of the psychiatrist respecting the established criteria applied in the practice of the Clinic for Psychiatry of the University Hospital Centre Rijeka. Patient diagnoses included schizophrenia, schizotypal, delusional, and other non-mood psychotic disorders (F20-F29), and mood (affective) disorders (F30-F39). The exclusion criteria were: 1) mental and behavioural disorders due to psychoactive substance use, 2) mental disorder caused by organic factors and 3 ) sensory or cognitive disabilities. All participants were informed of the purpose and procedures of the study and signed their informed consent.

\section{Instruments}

Basic sociodemographic data and information on psychiatric treatment were collected by a short questionnaire created for the purposes of this research. Sociodemographic data included age, gender, education, employment, marital status and housing conditions. Information on psychiatric treatment included the number of years since the first visit to the psychiatrist, the number of previous hospitalizations, and the number of days spent in the hospital during the last hospitalization.

Treatment satisfaction was registered using the Short Assessment of Patient Satisfaction (SAPS) questionnaire (14). The SAPS consists of seven items assessing the core domains of patient satisfaction which include treatment satisfaction, explanation of treatment results, clinician care, participation in medical decision-making, respect by the clinician, time with the clinician, and satisfaction with hospital/clinic care. The participant's responses are recorded on a 5-point scale. The questionnaire showed 
satisfactory metric characteristics (Cronbach $\alpha=0.86$ ) in clinical trials and a high degree of correlation with other more extensive measures of patient satisfaction. In this study, Cronbach's alpha was slightly lower $(\alpha=0.75)$ but still satisfactorily reliable. SAPS is a generic measure of patient satisfaction and can be used to assess satisfaction with different forms of treatment with different groups of patients. Another advantage is that it is short and easy to use so most patients only need a few minutes to complete it.

Quality of life was registered with the Manchester Short Assessment of Quality of Life (MANSA) (15). The instrument consists of 16 items. Twelve questions represent subjective measures of quality of life and include satisfaction with life as a whole, job satisfaction (training/education, or unemployment/ retirement), financial situation, number and quality of friendships, leisure activities, accommodation, personal safety, people with whom the patient lives (or single life), sex life, family relationships, physical health, and mental health. Participants rate these domains using a 7-point scale. Four items are considered objective measures of quality of life and the participant answers them with 'yes' or 'no'. These items assess whether a person has a close friend, has been in contact with friends in the past week, has been charged with a criminal offense in the past year, and has been a victim of physical violence. The Croatian language version of the questionnaire was validated and used in mental health research showing good metric characteristics (16). In this research, Cronbach's alpha was 0,89 indicating very good reliability.

\section{Procedure}

The study has been approved by the Ethics Committee of the Clinical Hospital Centre Rijeka and the Ethics Committee for Biomedical Research of the Faculty of Health Studies, University of Rijeka. Participants were informed of the purpose and procedures of the research and signed their informed consent. Participation in the study was voluntary and data collection through questionnaires was anonymous. The study was conducted in accordance with all ethical principles and human rights in research. Participants were given detailed instructions before completing the questionnaire, and in case of any ambiguities, they could ask the researcher. For the hospitalized patients, data were collected on the last day of hospitalization, while participants treated in the day hos- pital program completed questionnaires on the last day of day hospital treatment. Data collection was carried out over 2 months (from March to May 2019).

\section{Data analysis}

Descriptive statistics for categorical data were presented as absolute and relative frequencies. For continuous measures, means (standard deviations - SD) and medians (interquartile ranges) were presented where appropriate. Differences in sociodemographic and clinical characteristics between the hospitalized and day hospital patients were examined by the chisquare test. Normality of distributions of continuous measures was examined by the Kolmogorov-Smirnov test. Distributions of the individual domains of treatment satisfaction as well as the total score significantly differed from normal so the non-parametric Mann-Whitney $U$ test was used to examine the differences between the two groups of patients. Individual domains of subjective quality of life also significantly differed from a normal distribution, but not the total score, so the Mann-Whitney $U$ test was used for differences in a particular domain and student t-test for independent samples for the overall result. The level of statistical significance was set at two-tailed $p<0.05$ with $95 \%$ confidence intervals. All statistical analyses were performed using the statistical software SPSS 23 (SPSS Inc., Chicago, IL, USA).

\section{Results}

The study involved 120 participants treated at the Psychiatry clinic, Clinical Hospital Centre Rijeka. The first group were the patients included in the day hospital program, while the second group were participants at the inpatient hospital care. The two groups were matched by age, gender, level of education and employment status, but they differed by marital status. There were significantly more married/ cohabitating participants in the hospitalized group $\left(\chi^{2}=13.91 ; p=0.008\right)$. The two groups did not differ in the proportion of patients with schizophrenia, schizotypal, delusional, and other psychotic disorders (F20-F29), and mood (affective) disorders (F30-F39) but differed in some treatment characteristics. A sig- 
nificantly higher proportion of day hospital patients had been treated for more than 5 years compared to hospitalized patients $\left(\chi^{2}=12.46 ; p=0.006\right)$. Also, the duration of the last hospitalization was significantly longer for the day hospital group $\left(\chi^{2}=6.03 ; p=0.049\right)$ (Table 1). Significant "p" values are marked in bold in all tables.

Day hospital patients reported a significantly higher level of overall treatment satisfaction compared to hospitalized patients (Mann-Whitney $\mathrm{U}=1090$; $p=0.000$ ). Participants attending a day hospital program were more satisfied in four out of seven different treatment domains: the explanations about treatment $(p=0.013)$, carefulness and precision of medical examination $(p<0.001)$, choices about treatment $(p=0.027)$ and feeling of respect $(p=0.010)$. The groups did not significantly differ in satisfaction with the treatment effect, feeling that the time they had with the doctor/other health professional was too short and satisfaction with the care they received in the hospital/clinic (Table 2).

The results of the SAPS questionnaire can generally be grouped in three categories (14). A score ranging from 0 to 10 indicates poor health care and the need to urgently change the treatment or procedures the patient is receiving. In our study, the median satisfaction of both day hospital patients and ward patients was above this score.

In the next category, the results range from 11 to 18. Participants whose score falls into this range answered at least two questions (two aspects of their health care) with "dissatisfied" or "very dissatisfied" or did not answer any of the questions with "very satisfied." The median score of patients hospitalized on the ward was 17 indicating inadequate health care in several areas of their treatment and the need

Table 1. Differences in sociodemographic and psychiatric treatment characteristics between hospitalized and day hospital patients $(n=120)$

\begin{tabular}{|c|c|c|c|c|}
\hline & $\begin{array}{c}\text { Day hospital } \\
n=60\end{array}$ & $\begin{array}{c}\text { Hospitalized } \\
n=60\end{array}$ & & \\
\hline Age (years) & $n(\%)$ & $n(\%)$ & $\chi^{2}$ & $p$ \\
\hline $18-25$ & $1(1.6)$ & $4(6.7)$ & \multirow{5}{*}{8.62} & \multirow{5}{*}{0.071} \\
\hline $26-35$ & $10(16.7)$ & $7(11.7)$ & & \\
\hline $36-45$ & $7(11.7)$ & $14(23.3)$ & & \\
\hline $45-60$ & $21(35.0)$ & $14(23.3)$ & & \\
\hline$>60$ & $21(35.0)$ & $21(35.0)$ & & \\
\hline \multicolumn{5}{|l|}{ Gender } \\
\hline Female & $24(40.0)$ & $26(43.3)$ & \multirow{2}{*}{0.14} & \multirow{2}{*}{0.853} \\
\hline Male & $36(60.0)$ & $34(56.7)$ & & \\
\hline \multicolumn{5}{|l|}{ Education level } \\
\hline None or primary & $8(13.3)$ & $13(21.7)$ & \multirow{3}{*}{3.54} & \multirow{3}{*}{0.170} \\
\hline Secondary & $42(70.0)$ & $32(53.3)$ & & \\
\hline Higher & $10(16.6)$ & $15(25.0)$ & & \\
\hline \multicolumn{5}{|l|}{ Employment status } \\
\hline Employed & $13(21.7)$ & $13(21.7)$ & \multirow{3}{*}{2.21} & \multirow{3}{*}{0.531} \\
\hline Unemployed & $21(35.0)$ & $24(40.0)$ & & \\
\hline Retired & 26 (43.3) & $23(38.3)$ & & \\
\hline \multicolumn{5}{|l|}{ Marital status } \\
\hline Married/cohabiting & $17(28.3)$ & $32(53.3)$ & \multirow{4}{*}{13.91} & \multirow{4}{*}{0.008} \\
\hline Single & $33(55.0)$ & $14(23.3)$ & & \\
\hline Divorced & 7 (11.7) & $9(15.0)$ & & \\
\hline Widowed & $3(5.0)$ & $5(8.4)$ & & \\
\hline
\end{tabular}




\begin{tabular}{|c|c|c|c|c|}
\hline & $\begin{array}{c}\text { Day hospital } \\
n=60\end{array}$ & $\begin{array}{l}\text { Hospitalized } \\
n=60\end{array}$ & & \\
\hline \multicolumn{5}{|l|}{ Accommodation } \\
\hline Owned or rented & 35 (58.3) & $43(71.7)$ & \multirow{3}{*}{4.26} & \multirow{3}{*}{0.118} \\
\hline With parents & $23(38.3)$ & $13(21.7)$ & & \\
\hline $\begin{array}{l}\text { Social housing or } \\
\text { institution }\end{array}$ & $2(3.4)$ & $4(6.8)$ & & \\
\hline \multicolumn{5}{|l|}{ Diagnostic category } \\
\hline$F 20-F 29$ & $19(31,7)$ & $27(45,0)$ & \multirow{2}{*}{2,26} & \multirow{2}{*}{0,133} \\
\hline F30 - F39 & $41(68,3)$ & $33(55,0)$ & & \\
\hline \multicolumn{5}{|l|}{ Years in psychiatric treatment } \\
\hline$<1$ & $9(15.0)$ & $8(13.3)$ & \multirow{4}{*}{12.46} & \multirow{4}{*}{0.006} \\
\hline $1-2$ & $8(13.3)$ & $17(28.3)$ & & \\
\hline $3-5$ & $5(8.3)$ & $14(23.3)$ & & \\
\hline$>5$ & $38(63.3)$ & $21(35.0)$ & & \\
\hline \multicolumn{5}{|l|}{ Number of hospitalizations } \\
\hline 1 & $12(20.0)$ & $13(21.7)$ & \multirow{5}{*}{7.61} & \multirow{5}{*}{0.179} \\
\hline 2 & $8(13.3)$ & $15(25.0)$ & & \\
\hline 3 & $9(15.0)$ & $13(21.7)$ & & \\
\hline 4 & $4(6.7)$ & $5(8.3)$ & & \\
\hline 5 and more & $27(45.0)$ & $14(23.3)$ & & \\
\hline \multicolumn{5}{|l|}{$\begin{array}{l}\text { Duration of last hospitalization } \\
\text { (days) }\end{array}$} \\
\hline $1-10$ & $14(23.3)$ & $25(41.7)$ & \multirow{3}{*}{6.03} & \multirow{3}{*}{0.049} \\
\hline $11-20$ & 26 (43.3) & $26(43.3)$ & & \\
\hline$<20$ & 20 (33.3) & $9(15.0)$ & & \\
\hline
\end{tabular}

to change certain procedures. Treatment satisfaction of the day hospital patients is in the following category, which includes the range of results from 19 to 26 (median=20). This score indicates relatively high satisfaction with most services and forms of health care or applied therapeutic procedures. Day hospital patients answered more than half of the questions with "satisfied" or "very satisfied". Also, the level of satisfaction of the day hospital patients suggests that participants are more satisfied with particular segments of care, from communication and interaction with physicians or other health care staff, explanations related to illness and course of treatment, time devoted to treatment to various other treatment details. In a hospitalized group, a significant number of patients also stated that they are satisfied with the effectiveness of their treatment, but there were
$10 \%$ to $20 \%$ of those who were "dissatisfied" or "very dissatisfied."

Day hospital patients reported a significantly higher level of subjective quality of life compared to hospitalized patients ( $\mathrm{t}=2.89 ; \mathrm{p}=0.005$ ) (Table 3 ).

Participants attending day hospital program were more satisfied with life in general $(p=0.018)$, financial situation $(p=0.046)$, accommodation $(p=0.041)$, personal safety $(p=0.014)$, people they live with or living alone $(p=0.001)$, relationship with their family $(p<0.001)$ and their mental health $(p=0.008)$. The most prominent differences were in the domains of family relationships, satisfaction with people they live with or living alone, mental health and personal safety. The groups did not differ in other domains of subjective quality of life, as well as in four items related to objective quality of life (Table 4). 
Table 2. Differences in treatment satisfaction between hospitalized and day hospital patients $(\mathbf{n = 1 2 0})$

\begin{tabular}{|c|c|c|c|c|c|c|}
\hline \multirow[b]{2}{*}{ SAPS } & \multicolumn{2}{|c|}{$\begin{array}{l}\text { Day hospital } \\
n=60\end{array}$} & \multicolumn{2}{|c|}{$\begin{array}{l}\text { Hospitalized } \\
n=60\end{array}$} & \multirow[b]{2}{*}{$\begin{array}{l}\text { Mann- } \\
\text { Whitney U }\end{array}$} & \multirow[b]{2}{*}{$p$} \\
\hline & $\begin{array}{l}\text { Median } \\
\text { (interquar- } \\
\text { tile range) } \\
\end{array}$ & Mean rank & $\begin{array}{l}\text { Median } \\
\text { (interquar- } \\
\text { tile range) } \\
\end{array}$ & Mean rank & & \\
\hline $\begin{array}{l}\text { Satisfaction with the effect of your } \\
\text { overall treatment/care }\end{array}$ & $4(4-5)$ & 66.04 & $4(3-4)$ & 54.96 & 1467.50 & 0.058 \\
\hline $\begin{array}{l}\text { Satisfaction with the explanations } \\
\text { the doctor/other health professional } \\
\text { has given you about the results of } \\
\text { your treatment/care }\end{array}$ & $4(3.25-4)$ & 67.78 & $4(3-4)$ & 53.23 & 1363.50 & 0.013 \\
\hline $\begin{array}{l}\text { Satisfaction with how was the doc- } \\
\text { tor/other health professional careful } \\
\text { to check everything when examining } \\
\text { you }\end{array}$ & $4(4-5)$ & 71.92 & $4(3-4)$ & 49.08 & 1115.00 & 0.000 \\
\hline $\begin{array}{l}\text { Satisfaction with the choices you had } \\
\text { in decisions affecting your health care }\end{array}$ & $4(3-4)$ & 66.95 & $4(3-4)$ & 57.05 & 1413.00 & 0.027 \\
\hline $\begin{array}{l}\text { Feeling respected by the doctor/other } \\
\text { health professional }\end{array}$ & $4(4-5)$ & 68,27 & $4(3-5)$ & 52.73 & 1334.00 & 0.010 \\
\hline $\begin{array}{l}\text { Feeling that the time you had with } \\
\text { the doctor/other health professional } \\
\text { was too short }\end{array}$ & $3(2-4)$ & 62,86 & $3(2-4)$ & 58.14 & 1658.50 & 0.440 \\
\hline $\begin{array}{l}\text { Satisfaction with the care you re- } \\
\text { ceived in the hospital/clinic }\end{array}$ & $4(4-5)$ & 65,22 & $4(3-4)$ & 55.78 & 1517.00 & 0.100 \\
\hline SAPS total & $\begin{array}{l}20(18,25- \\
22,00)\end{array}$ & 72.33 & $\begin{array}{l}17(16.00- \\
20.75)\end{array}$ & 48.67 & 1090.00 & 0.000 \\
\hline
\end{tabular}

\section{Discussion}

The main goal of this study was to compare the satisfaction with the effectiveness of the treatment of the inpatient and day hospital program from the perspective of the patients with mental illness. The basic outcomes were satisfaction with the treatment and the quality of life.

The first segment of treatment satisfaction relates to general satisfaction with the effectiveness of treatment. Day hospital patients were more satisfied with the effectiveness of treatment compared to hospitalized patients. How this treatment efficacy was manifested cannot be precisely defined, but it can be assumed that day hospital patients felt subjectively better in terms of improving symptoms, increasing the level of general functionality, etc., and attributed this to treatment within the day hospital program. It is illustrative that in the group of day hospital patient no one answered this question with "dissatisfied" or "very dissatisfied", which in another way indicates the general level of satisfaction with the efficiency of the day hospital. On the other hand, the level of satisfaction with the treatment effectiveness of hospitalized patients was lower compared to a day hospital, however, it is not extremely low. The organization of the day hospital program, the involvement of the patient in the organization of activities, a more open and humane approach and other aspects of day hospital treatment seem to change the established patterns of communication between doctor/staff patient. It can also be assumed that doctors involved in day hospital activities were also likely to have 
Table 3. Differences in subjective quality of life between hospitalized and day hospital patients $(n=120)$

\begin{tabular}{|c|c|c|c|c|c|c|}
\hline & $\begin{array}{r}\text { Day ho: } \\
n=6\end{array}$ & $\begin{array}{l}\text { spital } \\
\text { i0 }\end{array}$ & $\begin{array}{r}\text { Hospita } \\
n=6\end{array}$ & lized & & \\
\hline MANSA - subjective quality of life & $\begin{array}{c}\text { Median } \\
\text { (interquartile } \\
\text { range) }\end{array}$ & Mean rank & $\begin{array}{c}\text { Median } \\
\text { (interquartile } \\
\text { range) }\end{array}$ & Mean rank & $\begin{array}{c}\text { Mann-Whitney } \\
\text { U }\end{array}$ & $p$ \\
\hline Satisfaction with life in general & $4.5(3-5)$ & 67.82 & $4(3-4.75)$ & 53.18 & 1361.00 & 0.018 \\
\hline $\begin{array}{l}\text { Satisfaction with employment/ } \\
\text { retirement }\end{array}$ & $4(3-5)$ & 66.01 & $3(2-5)$ & 54.99 & 1469.50 & 0.077 \\
\hline Satisfaction with financial situation & $4(3-5)$ & 66.72 & $3(2-4.75)$ & 54.28 & 1427.00 & 0.046 \\
\hline Satisfaction with friendships & $4(2-5)$ & 58.71 & $4(3-5)$ & 62.29 & 1692.50 & 0.566 \\
\hline Satisfaction with leisure activities & $4(3-5)$ & 63.59 & $4(3-5)$ & 57.41 & 1614.50 & 0.322 \\
\hline Satisfaction with accommodation & $5(3-6)$ & 66.85 & $4(3-5)$ & 54.15 & 1419.00 & 0.041 \\
\hline Satisfaction with personal safety & $5(4-6)$ & 68,12 & $4(3-5)$ & 52,58 & 1343,00 & 0,014 \\
\hline $\begin{array}{l}\text { Satisfaction with people living with/ } \\
\text { living alone }\end{array}$ & $5(4-6)$ & 70.99 & $4(3-5)$ & 50.01 & 1170.50 & 0.001 \\
\hline Satisfaction with sex life & $4(2-5)$ & 66.17 & $3(1.25-4.75)$ & 54.83 & 1460.00 & 0.069 \\
\hline $\begin{array}{l}\text { Satisfaction with relationship with } \\
\text { family }\end{array}$ & $5.5(5-6)$ & 71.98 & $4(3-5)$ & 49.03 & 1111.50 & 0.000 \\
\hline Satisfaction with physical health & $4(3-5)$ & 66.03 & $4(2-5)$ & 54.97 & 1468.00 & 0.076 \\
\hline Satisfaction with mental health & $5(3-5)$ & 68.74 & $3(3-4)$ & 52.26 & 1305.50 & 0.008 \\
\hline & \multicolumn{2}{|c|}{ Mean (SD) } & \multicolumn{2}{|c|}{ Mean (SD) } & $\mathrm{t}$ & $p$ \\
\hline Total score & \multicolumn{2}{|c|}{$4.26(1.11)$} & \multicolumn{2}{|c|}{$3.71(0.96)$} & 2.89 & 0.005 \\
\hline
\end{tabular}

Table 4. Differences in objective quality of life between hospitalized and day hospital patients (n=120)

\begin{tabular}{|c|c|c|c|c|c|c|}
\hline & \multicolumn{2}{|c|}{$\begin{array}{c}\text { Day hospital } \\
n=60\end{array}$} & \multicolumn{2}{|c|}{$\begin{array}{l}\text { Hospitalized } \\
\qquad=60\end{array}$} & \multirow[b]{2}{*}{$\chi^{2}$} & \multirow[b]{2}{*}{$p$} \\
\hline $\begin{array}{c}\text { MANSA - objective quality of } \\
\text { life } \\
\mathrm{n}(\%)\end{array}$ & yes & no & yes & no & & \\
\hline Do you have a close friend? & 44 (73.3) & $16(26.7)$ & 47 (78.3) & $13(21.7)$ & 0,41 & 0.670 \\
\hline $\begin{array}{l}\text { Have you been in contact with } \\
\text { friends in the past week? }\end{array}$ & 41 (68.3) & 19 (31.7) & 44 (73.3) & $16(26.7)$ & 0.36 & 0.688 \\
\hline $\begin{array}{l}\text { Have you been charged with a } \\
\text { criminal offense in the past year? }\end{array}$ & $2(3.3)$ & 58 (96.7) & $4(6.7)$ & 56 (93.3) & 0.70 & 0.679 \\
\hline $\begin{array}{l}\text { Have you been a victim of physi- } \\
\text { cal violence? }\end{array}$ & $1(1.7)$ & 59 (98.3) & 7 (11.7) & 53 (88.3) & 4.82 & 0.061 \\
\hline
\end{tabular}


more time and opportunities to get to know their patients better and developed a relationship that was less based on hierarchy and more on mutual respect. Also, the organizational structure and closeness of hospital treatment to a greater extent support traditional hierarchical patterns in which the doctor determines the course and method of treatment, and the patient's duty is to listen, not ask much and accept the doctor's instructions without discussion. In such conditions, patients often feel disrespected, neglected, and generally dissatisfied with treatment.

The results obtained are consistent with a number of studies showing that the treatment of patients with mental disorders within the day hospital is associated with greater treatment satisfaction. Somewhat similar results were obtained in the study of Dick et al. (11) comparing satisfaction with the treatment of patients diagnosed with neurosis, personality disorder, or adjustment disorder treated in a day hospital program with patients hospitalized on the ward. Measures of clinical outcomes, after the follow-up period, did not differ between hospitalized and day hospital patients, however, treatment satisfaction was significantly higher in day hospital patients (11). The results of a study by Priebe et al. (12) also showed that treatment satisfaction was significantly higher in patients treated in the day hospital. And in an extensive meta-analysis by Marshall et al. (9) it was also shown that the results of most of the included studies support the effectiveness of day hospital treatment in terms of greater treatment satisfaction, reduction of hospital days and the need for subsequent hospitalizations, and lower overall treatment costs.

Another measure of day hospital efficiency was quality of life with the hypothesis that patients treated within the day hospital would have a higher overall level of quality of life compared to patients hospitalized on the ward. The obtained results confirmed the hypothesis. A comparison of individual segments of quality of life showed that day hospital patients were significantly more satisfied with their lives as a whole, they were more satisfied with their material or financial situation, accommodation and the level of personal security. From the aspect of social functioning, participants treated in a day hospital were more satisfied with the people they live with or living as singles and relationships with their family. In addition, day hospital patients were significantly more satisfied with their mental health. Domains of quality of life in which there was no significant difference be- tween day hospital patients and those hospitalized in the ward were job satisfaction/schooling or retirement, quality and number of friends, leisure activities, sexual life and satisfaction with physical health. Therapeutic interventions within the day hospital program appear to have had some impact on the general level of quality of life and in particular on some aspects of social functioning. This result is easy to understand if we take into account that a good part of the day hospital program is precisely focused on developing social skills. The therapy group itself is a small social community in which participants have the opportunity to practice different models of communication. Patients are encouraged to participate as actively as possible in all processes within the group, emphasizing responsibility for themselves and cooperation with others. It is also useful that patients are not excluded from their primary community and family during the day hospital program, so they can apply and practice the skills learned in the day hospital on a daily basis in their own social environment. This allows for a gradual change in behaviour and improves their functioning in the "real world". Most of the effects described above are more difficult within hospital wards with patients who are isolated from their primary social environment. Despite the clear advantages of day hospital treatment in terms of developing social skills and increasing social competence, day hospital patients did not have a higher score in all social domains of quality of life. Satisfaction with friendships and leisure activities did not differ across groups. The results in these domains ranged on average from "mostly dissatisfied" to "neither satisfied nor dissatisfied", so it seems that both groups had certain problems in establishing and maintaining friendly relations and leisure activities. Another domain in which day hospital patients had significantly higher score is mental health. Although no clinical outcomes were examined in this study, this result is important because it indirectly indicates the level of symptomatology. Patients more satisfied with their mental health are likely to have a less severe clinical picture, while those who are generally dissatisfied are more likely to have higher levels of symptoms. In addition to subjective measures, 4 objective measures of quality of life were examined: whether a person has a close friend, whether he has been in contact with friends in the past week, whether a person has been charged with a crime in the last year and whether he has been a victim of physical vio- 
Vranješ J. et al. Quality of Life and Treatment Satisfaction of Hospitalized and Day Hospital Psych.Pat. Croat Nurs J. 2021; 5(1): 5-16

lence. No significant difference was found in any of these domains.

Numerous studies have shown that patients treated in day hospital programs have a higher level of quality of life compared to hospitalized patients treated in conventional psychiatric wards $(9,12,13)$. A study comparing the efficacy and cost of acute day-hospital treatment and traditional inpatient treatment showed that patients treated in the day hospital program had a lower level of psychopathology, higher satisfaction with treatment and a higher level of subjective quality of life (12); which is consistent with the results obtained in our study.

Our results are also in line with the study that examined the effectiveness of day hospital treatment of patients with schizophrenia, which showed that patients who, after hospitalization, underwent treatment in a day hospital have a significantly higher quality of life at the end of treatment and 6 months after completion of day hospital (13). Finally, a metaanalysis by Marshall et al. (9) that included numerous studies of day hospital efficacy, encompassing different clinical and social outcomes, showed that day hospital programs are generally more effective in treating mental disorders, especially when it comes to improving patient quality of life. However, it is important to emphasize that the differences obtained in our study may be related to the different severity of the illness in patients of the two groups. The severity of symptoms was not directly examined, but differences in the length of psychiatric treatment and the duration of the last hospitalization could indicate that patients treated within the day hospital had less severe symptoms and milder illness.

This research has several limitations that need to be considered when interpreting and generalizing results. First, the participants were not randomly assigned to a day hospital or inpatient treatment but were selected according to the established criteria applied in the practice of the Clinic for Psychiatry of the University Hospital Centre Rijeka. Although matched by most of the registered sociodemographic characteristics, it is possible that the examined groups were not balanced in other relevant factors. For example, patients treated in a day hospital program were likely to be more motivated and had greater capacity and resources to improve their mental health. It is also possible that their general clinical condition was milder than in hospitalized patients. Factors of this type could influence the outcomes of the research. Another limitation of the study to be considered are outcome measures. Only two outcomes were used in the study: the treatment satisfaction questionnaire (SAPS) and the quality of life questionnaire (MANSA), which are subjective self-assessment measures that may be influenced by a number of factors beyond the control of the researcher, such as current disease stage, acute symptoms, current mood and others. Another limitation is that it is a cross-sectional study that makes it impossible to monitor possible changes in outcomes over time and to link these changes to the effects of treatment.

With all the limitations, this research has its importance and quality. As already mentioned, this is a study conducted in a clinical setting taking into account the context and specific reality of the treatment. This "naturalistic" approach has made it possible to obtain relevant data on which to base future research that would include methodologically more rigorous designs. Despite the fact that psychiatric day hospitals have existed in Croatia for many years, only a few relatively small studies have investigated their effectiveness and we believe that this research will contribute to this under-researched area.

\section{Conclusion}

The results of this study showed that patients treated in the day hospital had a higher level of overall treatment satisfaction compared to hospitalized patients. In addition to the overall score, participants attending the day hospital program were more satisfied in four of the seven different domains of treatment: explanations of treatment, care and accuracy of medical examination, treatment choices, and a sense of respect.

Also, patients treated in a day hospital had a higher overall subjective quality of life score compared to patients hospitalized on a psychiatric ward. The most prominent differences were in the domains of family relationships, satisfaction with people they live with or living alone, mental health and personal safety. The groups did not differ in other domains of subjective quality of life and the four items related to objective quality of life. 


\section{References}

1. Mezzina R. Paradigm shift in psychiatry: processes and outcomes. In: Mental Health at the Crossroads. Routledge; 2017. p. 97-110.

2. Curral R, Lopes R, Silveira C, Norton A, Domingues I, Lopes $F$, et al. Forty years of a psychiatric day hospital. Trends Psychiatry Psychother. 2014;36(1):52-8.

3. Kazdin AE. Addressing the treatment gap: A key challenge for extending evidence-based psychosocial interventions. Behav Res Ther. 2017;88:7-18.

4. Chow WS, Priebe S. Understanding psychiatric institutionalization: a conceptual review. BMC Psychiatry. 2013;13(1):169.

5. Hudson CG. A model of deinstitutionalization of psychiatric care across 161 nations: 2001-2014. Int J Ment Health. 2016;45(2):135-53.

6. Kallert TW, Glöckner M, Priebe S, Briscoe J, Rymaszewska J, Adamowski T, et al. A comparison of psychiatric day hospitals in five European countries. Soc Psychiatry Psychiatr Epidemiol. 2004;39(10):77788.

7. Sledge WH, Tebes J, Rakfeldt J, Davidson L, Lyons L, Druss B. Day hospital/crisis respite care versus inpatient care, Part I: Clinical outcomes. Am J Psychiatry. 1996;153(8):1065-73.

8. Priebe $S$, McCabe R, Schützwohl M, Kiejna A, Nawka $P$, Raboch J, et al. Patient characteristics predicting better treatment outcomes in day hospitals compared with inpatient wards. Psychiatr Serv. 2011;62(3):27884.

9. Marshall M, Crowther R, Almaraz-Serrano A, Creed $F$, Sledge $W$, Kluiter $H$, et al. Systematic reviews of the effectiveness of day care for people with severe mental disorders:(1) acute day hospital versus admission;(2) vocational rehabilitation;(3) day hospital versus outpatient care. Health Technol Assess. 2001;5(21):1-75.

10. Stylianidis S, Trivellas D. A Modern-Day Community Daycare Centre in Operation. In: Social and Community Psychiatry. Springer; 2016. p. 215-47.

11. Dick P, Cameron L, Cohen D, Barlow M, Ince A. Day and full time psychiatric treatment: a controlled comparison. Br J Psychiatry. 1985;147:246-9.

12. Priebe $S$, Jones $G, M c C a b e ~ R$, Briscoe J, Wright $D$, Sleed $M$, et al. Effectiveness and costs of acute day hospital treatment compared with conventional in-patient care: randomised controlled trial. Br J Psychiatry. 2006;188:243-9.

13. Grahovac Juretić T, Ružić K, Letica-Crepulja M, Petrić D, Dadić-Hero E, Frančišković T. Effects of psychosocial day care programme on quality of life in patients affected with schizophrenia - A prospective study. Psychiatr Danub. 2016;28(2):111-7.

14. Hawthorne G, Sansoni J, Hayes L, Marosszeky N, Sansoni E. Measuring patient satisfaction with health care treatment using the Short Assessment of Patient Satisfaction measure delivered superior and robust satisfaction estimates. J Clin Epidemiol. 2014;67(5):527-37.

15. Priebe S, Huxley P, Knight S, Evans S. Application and results of the Manchester Short Assessment of Quality of Life (MANSA). Int J Soc Psychiatry. 1999;45(1):7-12.

16. Matanov A, Giacco D, Bogic M, Ajdukovic D, Franciskovic T, Galeazzi GM, et al. Subjective quality of life in war-affected populations. BMC Public Health. 2013;13:624. 


\section{KVALITETA ŽIVOTA I ZADOVOLJSTVO LIJEČENJEM HOSPITALIZIRANIH PSIHIJATRIJSKIH} BOLESNIKA I BOLESNIKA LIJECEENIH UNUTAR PROGRAMA DNEVNE BOLNICE

\section{Sažetak}

Uvod. Dnevne bolnice postaju sve češći oblik liječenja osoba s mentalnim poremećajima u mnogim psihijatrijskim klinikama u Hrvatskoj, ali istraživanja koja ispituju njihovu učinkovitost još uvijek su rijetka. Cilj. Cilj ovog istraživanja bio je usporediti zadovoljstvo liječenjem i kvalitetu života pacijenata liječenih unutar programa dnevne bolnice i pacijenata hospitaliziranih na psihijatrijskom odjelu.

Metode. Istraživanje je oblikovano kao presječna studija s dvije mjere ishoda: zadovoljstvo liječenjem i kvaliteta života. Uzorak se sastojao od 120 odraslih pacijenata Klinike za psihijatriju Kliničkoga bolničkog centra Rijeka. Prvu skupinu činilo je 60 pacijenata uključenih u psihosocijalni program dnevne bolnice, dok je drugu grupu činilo 60 pacijenata hospitaliziranih na bolničkom odjelu.

Rezultati. Pacijenti dnevne bolnice izvijestili su o značajno višem stupnju ukupnog zadovoljstva liječenjem u odnosu na hospitalizirane pacijente (srednji rang: 55 vs. 17, $p=0,000$ ) i bili su značajno zadovoljniji u četiri od sedam različitih područja liječenja: objašnjenja o liječenju (srednji rang: 68 vs. $53, p=0,013$ ), pažljivost i preciznost liječničkog pregleda (srednji rang: 72 vs. $49, p=0,000$ ), izbor liječenja (srednji rang: 67 vs. 57, $p=0,027$ ) i osjećaj poštovanja (srednji rang: 68 vs. 53, $p=0,010$ ). Pacijenti dnevne bolnice također su izvijestili o značajno višoj razini ukupne subjektivne kvalitete života (aritmetička sredina: 4,26 vs. 3,71, $p=0,005$ ). Zadovoljniji su životom općenito (srednji rang: 68 vs. 53, $p=0,018$ ), financijskom situacijom (srednji rang: 67 vs. 54, $p=0,046$ ), smještajem (srednji rang: 67 vs. 54, $p=0,041$ ), osobnom sigurnošću (srednji rang: 68 vs. $53, p=0,014)$, osobama s kojima žive ili time što žive sami (srednji rang: 71 vs. $50, p=0,001$ ), odnosima s obitelji (srednji rang: 72 vs. $49, p=0,000$ ) te mentalnim zdravljem (srednji rang: 69 vs. 52, $p=0,008$ ).

Zaključak. Pacijenti tretirani unutar dnevne bolnice i oni hospitalizirani na odjelu razlikovali su se, kako u zadovoljstvu tretmanom tako i u subjektivnoj kvaliteti života. Buduća istraživanja trebala bi se usredotočiti na različite segmente programa dnevnih bolnica te širi skup ishoda.

Ključne riječi: mentalni poremećaji, dnevna bolnica, zadovoljstvo tretmanom, kvaliteta života 